\title{
PREFERENSI KOMUNIKASI PEMASARAN TERPADU PERGURUAN TINGGI DI SURABAYA PADA ERA POSMODEREN
}

\section{Preferences of Integrated Marketing Communication of University at Surabaya in Postmodern Era}

\author{
1) *Hilda Yunita Wono, ${ }^{2)}$ Imanuel Deny Krisna Aji \\ 1) 2) Universitas Ciputra Surabaya \\ Citraland CBD Boulevard 60219-Surabaya
}

Diterima 24 Mei 2020/Disetujui 19 September 2020

\begin{abstract}
This study aims to determine the activities of Integrated Marketing Communication (IMC) which is the preference of students at the private university in Surabaya. This research is a quantitative type of research using the slovin method and stratified random sampling combined with purposive sampling as a sampling method. Existing data is processed using SPSS Statistics so that the data is presented in tabular form as data analysis. The results of this study were found IMC activities that are considered the most preferred by college students, starting from the most preferred by giving a ranking of one to sixth. In this study obtained a sequence starting from the first rank to the sixth rank according to the results of the survey to respondents ranging from discounted scholarships, education exhibitions at schools, news in the mass media, the existence of call center and social services, billboards on the highway, parents dinner.
\end{abstract}

Keywords: integrated marketing communication, preferences, private universities

\begin{abstract}
ABSTRAK
Penelitian ini bertujuan untuk mengetahui kegiatan komunikasi pemasaran terpadu yang menjadi preferensi mahasiswa pada perguruan tinggi di Kota Surabaya. Penelitian ini merupakan penelitian berjenis kuantitatif. Penentuan sampel dari populasi mahasiswa di Surabaya mengunakan rumus Slovin, sementara penarikan sampel menggunakan metode stratified random sampling yang dikombinasikan dengan purposive sampling. Data diolah menggunakan perangkat lunak SPSS versi 17, dan disajikan dalam bentuk tabel sebagai analisis data, yang hasilnya ditampilkan berupa prosentase. Hasil penelitian menunjukkan, ditemukan kegiatan komunikasi pemasaran terpadu yang dianggap paling disukai oleh mahasiswa perguruan tinggi di Surabaya, mulai dari yang paling disukai dengan pemberian peringkat satu hingga peringkat ke enam adalah beasiswa, pameran pendidikan di sekolah, berita di media massa, adanya layanan call center dan medsos, billboard di jalan raya, serta parents dinner.
\end{abstract}

Kata kunci: komunikasi pemasaran terpadu, preferensi, perguruan tinggi swasta

*Korespondensi penulis:

Email: hilda.yunita@ciputra.ac.id

\section{PENDAHULUAN}

Perguruan tinggi merupakan salah satu instansi yang berfokus dalam mengadakan suatu program dalam bidang pendidikan akademik yang dilakukan secara profesional dalam disiplin ilmu pengetahuan teknologi dan kreativitas tertentu sehingga dapat tercipta sumber daya manusia yang berkualitas (Adisetiawan, 2016). Dalam hal ini masyarakat Indonesia sudah mulai menyadari 
bahwa perguruan tinggi merupakan jenjang yang sangat penting untuk menciptakan SDM yang berkualitas sehingga melalui perguruan tinggi seluruh potensi yang ada dalam diri manusia dapat dimanfaatkan secara optimal apabila potensi itu terus dipelajari dan dikembangkan. Pengembangan potensi yang dilakukan perguruan tinggi memiliki peran yang cukup besar untuk mencetak SDM yang berkualitas dan berdaya saing baik di kancah Nasional maupun Internasional terutama pada jaman posmoderen saat ini.

Menurut Ristek Dikti (2016) pada penelitiannya yang dilakukan pada tahun 2017 diperoleh data terkait jumlah perguruan tinggi di Indonesia yaitu 4.504 unit perguruan tinggi yang terdaftar di Indoenesia. Perguruan tinggi tersebut terdiri dari 3.136 unit Perguruan Tinggi Swasta (PTS) dan 122 unit Perguruan Tinggi Negeri (PTN) (Databoks, 2017). Dari data tersebut dapat disimpulkan bahwa persaingan antar perguruan tinggi semakin ketat. Hal ini juga dapat menyebabkan perguruan tinggi baik swasta maupun negeri dituntut harus memiliki strategi-strategi pemasaran yang tepat dan efektif sehingga nilai-nilai perguruan tinggi dapat tersebarluaskan di mana hal tersebut dapat berdampak kepada meningkatnya minat mahasiswa baru untuk mendaftar di perguruan tinggi baik swasta maupun negeri tersebut.

Pemasaran dalam sebuah instansi pendidikan juga sangat dibutuhkan, namun dalam, hal instansi pendidikan suatu pemasaran bukanlah sekedar mencari keuntungan atau laba sebesar-besarnya melainkan juga untuk memberikan pelayanan yang prima kepada pelanggan pendidikan, terutama masyarakat yang berekspektasi tinggi kepada dunia pendidikan yang ada saat ini dimana dalam hal ini pemasaran dapat menjadi kunci dalam kepuasan pelanggan (Raya, 2016). Peran komunikasi dalam suatu strategi pemasaran yaitu sebagai pembeda antara produk yang ingin ditawarkan oleh perusahaan yang satu dengan perusahaan yang lainnya yang biasa disebut differentiating terutama pada jaman posmoderen yang banyak sekali terjadi peubahan dalam kehidupan di masyarakat (Teguh \& Ciawati, 2020). Diferensiasi suatu produk dapat berupa seperti nama merek, kemasan, warna dan rasanya. Komunikasi dalam suatu startegi pemasaran juga dapat digunakan untuk membujuk, menginformasikan dan sebagai penghantar nilai-nilai sosial dari sebuah perusahaan atau instansi kepada masyarakat luas (Utami, Lestari, \& Putri, 2016).

Perguruan tinggi yang cenderung berpikiran tradisional, tidak inovatif serta berharap tidak adanya perubahan dalam berbagai hal tentu saja akan menemui banyak kesulitan (Srisusilawati, 2017). Untuk dapat meraskan efek dalam bidang pemasaran, maka perguruan tinggi dapat mengembangkan marketing communication strategy dengan menerapkan berbagai aktivitas marketing, tidak hanya kegiatan promosi tetapi juga melakukan komunikasi dengan para calon pelanggan atau target pasar. Perguruan tinggi pasti sadar bahwa persepsi calon mahasiswa terhadap suatu perguruan tinggi merupakan sintesis dari seperangkat kontak yang dialami dan pesan yang diterima oleh mereka. Sehingga semua elemen pemasaran layak untuk digunakan (Wibowo, 2014).

Sebagai lembaga pendidikan, perguruan tinggi dianggap sebagai organisasi sosial. Dalam sebuah organisasi yang bersifat sosial tetap perlu mengenalkan organisasinya kepada khalayak luas dikenal dengan komunikasi pemasaran sosial atau social marketing. Kegiatan komunikasi pemasaran sosial ini merupakan bentuk aplikasi dari teknik pemasaran komunikasi bisnis ke dalam program-program organisasi nirlaba yang disusun berdasarkan target individual untuk meningkatkan kesejahteraan personal, serta memenuhi kebutuhan manusia secara sensitif dan memuaskan (Ulfa \& Marta, 2016). Dalam sebuah komunikasi pemasaran sosial juga diperlukan Integrated Markerting Communication (IMC) yang berisi terkait strategi dan pedoman dalam membentuk dan melakukan suatu komunikasi pemasaran. Integrated Marketing Communication (IMC) biasanya digunakan untuk membentuk sebuah strategi komunikasi pemasaran yang baik dan tepat sesuai dengan target, segmentasi, dan posisi suatu produk di dalam sebuah pasar yang ada (Keke, 2015).

Menurut Isharyadi, Kurniawan, Irwansyah dan Ruliana (2019) Integrated Marketing Communication (IMC) adalah suatu proses komunikasi yang mana dalam pembentukan dan pelaksanaannya dibutuhkan perencanaan 
sehingga dapat menciptakan suatu integrasi dan implementasi dari beberapa bentuk komunikasi pemasaran yang dikenal dengan IMC tools. Bentuk dari IMC tools tersebut ada lima mulai dari periklanan yang merupakan bentuk promosi dan komunikasi berbayar. Contoh bentuk lainnya adalah promosi penjualan dan publisitas yang merupakan cara untuk mengembangkan citra suatu perusahaan. Dua tools selanjutnya yang biasa dilakukan oleh perusahaan dilakukan dengan mengadakan acara dan pengalaman yang merupakan bentuk komunikasi untuk mendekatkan diri atau menjalin kedekatan dengan calon konsumen atau konsumen. Yang terakhir adalah dengan melakukan penjualan personal yang merupakan bentuk komunikasi pemasaran bersifat tatap muka dan penjualan langsung yang merupakan bentuk komunikasi pemasaran yang disampaikan menggunakan customer database. Semua hal tersebut disampaikan kepada pelanggan atau calon pelanggan sebagai target marek yang mana berfungsi sebagai perantara penyampaian nilai-nilai sebuah perusahaan agar suatu perusahaan dapat bersaing.

Suatu strategi komunikasi pemasaran juga diperlukan di berbagai bidang atau jenis perusahaan tanpa terkecuali salah satunya adalah perusahaan atau instansi yang bergerak di bidang pendidikan. Strategi komunikasi pemasaran biasanya digunakan sebagai alat untuk memperkenalkan dan menyebarluaskan nilai-nilai suatu perusahaan maka dari itu salah satu bidang perusahaan atau instansi yang juga memerlukan hal ini adalah perusahaan yang bergerak di bidang pendidikan. Salah satu Perguruan Tinggi Swasta di Kota Surabaya telah menyadari pentingnya suatu strategi pemasaran yang tepat dan efektif untuk dapat menarik calon mahasiswa baru. Perguruan Tinggi Swasta tersebut menggunakan model komunikasi pemasaran yang terintegrasi dan mengkombinasikannya dengan ilmu lain seperti ilmu psikologi dan ilmu ekonomi. Dalam hal ini peran ilmu psikologi adalah untuk membantu Perguruan Tinggi Swasta tersebut untuk dapat membaca apa yang dibutuhkan dan diharapkan oleh calon mahasiswa baru terhadap Perguruan Tinggi Swasta yang ingin mereka masuki, sedangkan ilmu ekonomi menyangkut bagaimana
Perguruan Tinggi Swasta tersebut dapat mencapai hasil target penerimaan mahasiswa yang maksimum tetapi dengan sumber daya yang seminimum mungkin. Kegiatan ini tercermin dalam contoh-contoh yang ditampilkan pula dalam jurnal yang ditulis oleh Sinta Petri Lestari (2016) serta Adhi Gurmilang (2015).

Adapun beberapa kegiatan IMC yang telah dilakukan oleh perguruan tinggi swasta ini antara lain, kegiatan IMC pertama yang digunakan oleh perguruan tinggi swasta ini adalah periklanan atau advertising yang mana teori periklanan lebih dalam dijelaskan oleh Primadhany Kartana Putri (2016) serta Poluan, Lumintang, dan Untu (2016) yaitu merupakan sebuah kegiatan promosi yang dilakukan dengan mengirimkan pesan di mana pesan tersebut bersifat nonpersonal yang disebarluaskan lewat media berbayar sehingga dapat menjangkau pasar yang lebih luas. Sedangkan advertising juga dijelaskan segala bentuk komunikasi pemasaran yang bersifat berbayar yang mana pesan akan diberikan atau ditemukan dalam bentuk media cetak, media siaran, media digital ataupun media umum lainnya seperti banner, billboard, televisi, atau komunikasi pemasaran langsung yang ditargetkan kepada konsumen. Terdapat beberapa indikator dalam advertising menurut Kotler \& Keller (2009) yaitu, Informative advertising merupakan indikator yang memiliki tujuan untuk menciptakan kesadaran merek dan pengetahuan akan suatu produk baru atau fitur baru dari produk yang sudah ada. Kedua, Persuasive advertising merupakan indikator yang bertujuan untuk diskusi, sebagai preferensi, meyakinkan, dan adanya pembelian produk atau layanan. Ketiga, reminder advertising adalah salah satu indikator yang memiliki tujuan untuk mendorong adanya pembelian ulang suatu produk dan jasa. Keempat, reinforcement advertising adalah indikator yang memiliki tujuan untuk meyakinkan konsumen baru bahwa mereka telah melakukan keputusan yang tepat. Salah satu kegiatan dalam komponen periklanan ini yang digunakan perguruan tinggi swasta ini adalah dengan menggunakan sarana billboard yang dipasang di beberapa jalan besar dan jalan protokol 
yang mendapat perhatian khalayak dari masyarakat sekitar.

Kegiatan IMC kedua adalah promosi penjualan atau sales promotion yang mana dijelaskan menurut Lestari (2015) bahan inti dalam sebuah kampanye pemasaran, koleksi alat intensif yang mana sebagian besar bersifat jangka pendek dan dirancang untuk dapat menstimulasi niat pembelian konsumen yang lebih cepat atas suatu produk barang atau jasa tertentu. Sales promotion atau promosi penjualan menurut Krussell dan Paramita (2016) adalah kumpulan alat insentif jangka pendek oleh konsumen atau perdagangan yang menyebabkan terjadinya penjualan lebih cepat atau lebih besar dari produk tertentu, misalnya perusahaan menggunakan alat promosi penjualan seperti kupon, hadiah (giveaway) dan sejenisnya untuk menarik tanggapan yang lebih kuat dan lebih cepat menarik pembeli. Terdapat beberapa indikator pada sales promotion atau promosi penjualan yaitu yang pertama adalah sampling yang mana biasanya memberikan kepada konsumen percobaan suatu produk atau jasa. Kedua adalah Coupons yang mana merupakan alat promosi yang biasanya diberikan dalam bentuk pemberian hadiah kepada konsumen atau calon konsumen dengan menawarkan potongan harga atau barang gratis. Ketiga adalah Special Price yaitu kegiatan promosi penjualan atau sales promotion dengan cara memberikan potongan atau pengurangan harga dari harga normal yang diberikan yang biasa disebut dengan harga khusus. Keempat adalah sweepstakes, contests \& games merupakan salah satu bentuk kegiatan promosi penjualan yang dilakukan dengan cara memberikan kesempatan pada konsumen untuk memenangkan hadiah berupa barang atau uang. Dalam hal ini perguruan tinggi swasta ini memberikan diskon harga melalui pemberian beasiswa sebagai bentuk implementasi dari kegiatan promosi penjualan.

Kegiatan IMC ketiga adalah acara dan pengalaman yang merupakan serangkaian kegiatan yang diselenggarakan/disponsori oleh perusahaan dimana dalam kegiatan tersebut terdapat hubungan dengan suatu brand (Anjelin \& Wahyuni, 2018). Dalam hal ini perguruan tinggi swasta mengadakan parents dinner bagi orang tua calon mahasiswa perguruan tinggi swasta ini. Melalui acara parents dinner ini orang tua calon mahasiswa perguruan tinggi swasta dapat mendengarkan penjelasan lebih rinci tentang jurusan yang akan dimasuki oleh anak-anak mereka

Kegiatan IMC keempat adalah hubungan masyarakat dan publisitas yang dijelaskan oleh Prabela, Kumadji dan Mawardi (2016) merupakan suatu fungsi manajemen yang membangun dan mempertahankan hubungan yang baik dan bermanfaat antara suatu organisasi dan publik sehingga berpengaruh kepada kesuksesan organisasi tersebut. Selain itu, public relations juga merespon opini publik dan selalu terinformasi. Adanya media internet semakin memperluas aktivitas. Dalam hal ini perguruan tinggi swasta ini menggunakan media massa sebagai media untuk penyampaian berita-berita mengenai perguruan tinggi tersebut. Semua tegiatan IMC keempat ini berada di bawah koordinator Public relations dengan akses langsung kepada rektorat.

Kegiatan IMC kelima adalah penjualan personal yang dijelaskan Kusniadji bahwa kegiatan penjualan personal memiliki beberapa keunggulan salah satunya bersifat tatap muka sehingga penyampaian pesan akan lebih efektif sehingga probabilitas calon pelanggan atau pelanggan dapat terbujuk akan lebih tinggi (Kusniadji, Kontribusi Penggunaan Personal Selling Dalam Kegiatan Komunikasi Pemasaran Pada Era Pemasaran Masa Kini , 2017). Menurut Bill Chitty, Edwina Luck, Nigel Barker, Michael Valos dan Terrence A Shimp (2012) personal selling merupakan suatu bentuk komunikasi orang ke orang di mana seorang penjual bekerja dengan calon pembeli agar dapat mempengaruhi kebutuhan pembelian mereka ke arah produk atau jasa perusahaannya. Hal terpenting dari personal selling adalah penjualan pribadi yang melibatkan interaksi dengan orang lain. Tujuan utama dari personal selling adalah mengajarkan konsumen, menyediakan penggunaan produk dan bantuan pemasaran dan menyediakan layanan penjualan dan dukungan kepada pembeli.

Personal selling berkontribusi pada tingkat perhatian konsumen yang relatif tinggi, karena dalam menghadapi situasi sulit bagi pembeli potensial untuk menghindari 
wiraniaga penjual. Seorang penjual diharuskan untuk menyesuaikan pesan dengan minat dan kebutuhan khusus pelanggan. Aspek komunikasi dua arah personal selling menghasilkan umpan balik langsung. Dalam pengimplementasian kegiatan penjulan personal atau personal selling pada perguruan tinggi swasta ini biasanya memanfaatkan brosur yang mana digunakan untuk dibagikan kepada siswa-siswa di sekolah-sekolah SMA yang merupakan tempat penyelenggaraan pameran pendidikan mereka. Hal ini dilakukan rutin setiap tahun sesuai dengan masa pameran yang dilakukan setiap Sekolah Menengah Atas masing-masig.

Kegiatan IMC yang terakhir adalah pemasaran langsung yang dijelaskan Krussell dan Paramita (2016) bahwa pemasaran langsung dibedakan menjadi dua yaitu front end dan back operations di mana front end mencakup penawaran yang diberikan ke konsumen melalui customer database. Sedangkan back end adalah suatu usaha memenuhi harapan konsumen dengan cara membuat produk atau informasi seperti yang diekspektasikan konsumen. Terdapat beberapa bentuk dalam pemasaran langsung menurut Kotler \& Keller (2009), seperti telepon, online, dan secara pribadi. Ada tiga karakteristik berbeda dalam pesan pemasaran langsung, yang pertama adalah penyesuaian, dimana pesan dapat dipersiapkan untuk menarik konsumen yang dituju. Yang kedua adalah terkini, yang berarti sebuah pesan dapat dipersiapkan dengan sangat cepat. Yang ketiga adalah interaktif, dimana pesan dapat diubah tergantung pada tanggapan seseorang. Dalam penelitian ini Instagram adalah media yang digunakan oleh perguruan tinggi swasta ini dalam kegiatan pemasaran langsung di media sosial. Selain itu perguruan tinggi swasta ini juga memiliki call center yang selalu siap menjawab pertanyaan-pertanyaan seputar perguruan tinggi swasta ini lewat telepon.

Dari beberapa kegiatan pemasaran yang dilakukan oleh perguruan tinggi swasta tersebut, juga terdapat kendala yang ditemukan dalam pengelolaan biaya yang harus dikeluarkan oleh perguruan tinggi swasta tersebut yang mana tujuan dari pengelolaan dana adalah agar biaya yang di keluarkan untuk kegiatan komunikasi pemasarannnya dapat lebih efesien dan dapat lebih hemat atau seminimal mungkin namun memiliki dampak semaksimal mungkin. Dari latar belakang tersebut dan salah satu ciri yang paling terasa dari posmoderen adalah mengedepankan relativisme dalam berbagai hal. Kaum postmo melihat sebuah kebenaran sebagai sesuatu yang relatif. Hal ini membuat berbagai kegiatan pemasaran yang dilakukan ini selalu relatif dan memiliki urutan tingkat kesenangan tersendiri. Maka tujuan dari penelitian ini adalah untuk mengetahui kegiatan komunikasi pemasaran yang menjadi preferensi mahasiswa perguruan tinggi tersebut. Preferensi yang disampaikan oleh Bambang Supriadi dan Nanny Roedjinandari (2017) merupakan perilaku yang ada dalam diri seseorang menunjukkan sesuatu yang cenderung kepada satu hal saja, yaitu pasti ada yang lebih disukai dan menjadikannya sebagai pilihan utama atau prioritas dalam melakukan keputusan. Dalam penelitian ini, enam kegiatan IMC perguruan tinggi Surabaya digunakan untuk mengetahui urutan dari kegiatan tersebut mulai dari yang paling disukai konsumen. Didukung dengan penyampaian oleh Hilda Yunita Wono (2018) yang menyatakan bahwa preferensi muncul dari persepsi seseorang dalam suatu produk yang lebih disukai dan setiap individu pasti membuat penyusunan ranking terhadap suatu situasi, dari mulai hal yang disukai hingga yang tidak disukai.

\section{METODE PENELITIAN}

Metode penelitian yang digunakan dalam penelitian ini adalah dengan pendekatan kuantitatif dikarenakan data penelitian berupa angka dengan model analisis menggunakan statistik. Menurut Surjaweni (2015) metode penelitian kuantitatif penelitian yang memusatkan data di dalam suatu variabel yang kemudian dianalisis menggunakan teori yang objektif. Dengan populasi yang dipilih adalah mahasiswa di salah satu perguruan tinggi swasta di Surabaya dengan total 1179 mahasiswa dari 15 prodi. Pada penelitian ini juga digunakan rumus slovin sebagai metode sampling. Menurut Rahmat Kriyantono (2006) dan juga digunakan oleh Nasruhlhak 
Akkas (2016) rumus slovin digunakan untuk menentukan ukuran suatu sampel dari populasi yang diketahui jumlahnya. didapatkan hasil perhitungan sebagai berikut:

$\mathrm{n}: \mathrm{N} /\left(1+\left(\mathrm{N} \times e^{2}\right)\right)$

n: $1179 /\left(1+\left(1179 \times 0.05^{2}\right)\right)$

n: 298,6 dibulatkan menjadi 300 responden

Keterangan:

$\mathrm{n}$ : Ukuran Sampel (dicari)

$\mathrm{N}$ : Ukuran Populasi (1179 mahasiswa)

1: Bilangan Konstan

e : Kelonggaran ketidaktelitian karena kesalahan pengambilan sample

Dari hasil perhitungan di atas dapat dinyatakan bahwa jumlah minimum responden yang harus di dapatkan dalam penelitian ini adalah 300 responden. Terdapat metode yang digunakan dalam

penelitian ini untuk mendapatkan 300 resonden tersebut, maka dalam penelitian ini menggunakan stratified random sampling sebagai metode sampling. Stratified random sampling merupakan suatu metode yang digunakan jika ditemukan variasi yang terdapat pada antar data adalah besar (heterogen) dalam hal ini proporsi jumlah mahasiswa pada setiap prodi berbeda. Dalam penelitian ini juga menggunakan metode purposive sampling dalam metode samplingnya. Purposive sampling adalah teknik sampling yang digunaan pada penelitian yang lebih mengutamakan tujuan penelitian daripada sifat populasi dalam menentukan sample penelitian yang dipilih.

\section{HASIL DAN PEMBAHASAN}

Tabel 1 merupakan hasil analisis data tentang kegiatan IMC yang telah dilakukan oleh perguruan tinggi swasta ini diantaranya billboard di jalan raya, diskon beasiswa, parents dinner, berita di media massa, pameran pendidikan di sekolah-sekolah, dan adanya layanan call center dan media sosial yang sudah diolah menggunakan SPSS statistik.

Data di tabel 1 didapatkan dari 300 responden yang mana responden tersebut merupakan mahasiswa salah satu perguruan tinggi swasta di Surabaya pada angkatan 2018 dari semua program studi yang ada pada perguruan tinggi swasta tersebut.

Responden yang didapat dalam penelitian ini terdiri dari laki-laki dan perempuan dengan jumlah yaitu, 142 responden adalah laki-laki dan 158 responden adalah perempuan yang mana memiliki persentase antara laki-laki dan perempuan masing-masing yaitu, $47 \%$ dan $53 \%$ dari total jumlah responden yang ada. Berdasarkan tabel 1 tersebut, dapat dijelaskan: 
Tabel 1

Hasil Urutan Peringkat IMC

\begin{tabular}{|l|c|c|c|c|c|c|c|c|c|c|c|c|c|}
\hline Kegiatan IMC & 1 & $\%$ & 2 & $\%$ & 3 & $\%$ & 4 & $\%$ & 5 & $\%$ & 6 & $\%$ & \\
\hline $\begin{array}{l}\text { Billboard di } \\
\text { jalan raya }\end{array}$ & 36 & $12 \%$ & 39 & $13 \%$ & 39 & $13 \%$ & 51 & $17 \%$ & 69 & $23 \%$ & 66 & $22 \%$ & 300 \\
\hline $\begin{array}{l}\text { Diskon } \\
\text { beasiswa }\end{array}$ & 125 & $42 \%$ & 72 & $24 \%$ & 35 & $12 \%$ & 30 & $10 \%$ & 21 & $7 \%$ & 17 & $6 \%$ & 300 \\
\hline $\begin{array}{l}\text { Parents } \\
\text { dinner }\end{array}$ & 20 & $7 \%$ & 33 & $11 \%$ & 43 & $14 \%$ & 45 & $15 \%$ & 67 & $22 \%$ & 92 & $31 \%$ & 300 \\
\hline $\begin{array}{l}\text { Berita di } \\
\text { media massa }\end{array}$ & 24 & $8 \%$ & 57 & $19 \%$ & 82 & $27 \%$ & 67 & $22 \%$ & 51 & $17 \%$ & 19 & $6 \%$ & 300 \\
\hline $\begin{array}{l}\text { Pameran } \\
\text { pendidikan di } \\
\text { sekolah- } \\
\text { sekolah }\end{array}$ & 78 & $26 \%$ & 68 & $23 \%$ & 52 & $17 \%$ & 43 & $14 \%$ & 35 & $12 \%$ & 24 & $8 \%$ & 300 \\
\hline $\begin{array}{l}\text { Adanya } \\
\text { layanan call } \\
\text { center dan } \\
\text { media sosial }\end{array}$ & 17 & $6 \%$ & 31 & $10 \%$ & 49 & $16 \%$ & 64 & $21 \%$ & 57 & $19 \%$ & 82 & $27 \%$ & 300 \\
\hline Total & 300 & $100 \%$ & 300 & $100 \%$ & 300 & $100 \%$ & 300 & $100 \%$ & 300 & $100 \%$ & 300 & $100 \%$ & \\
\hline
\end{tabular}

Sumber: Diolah Peneliti, 2020

Kolom pertama berisikan 6 kegiatan IMC yang dilakukan oleh perguruan tinggi. Selanjutnya pada baris pertama berisikan angka serta tanda persen. Angka 1 menunjukkan urutan 1 yang dipilih oleh responden sebagai kegiatan yang membuat responden tersebut akhirnya ingin masuk dan berkuliah di perguruan tinggi tersebut. Selanjutnya nomor untuk kegiatan kedua yang membuat responden tertarik dan berkuliah di perguruan tinggi. Kegiatan Integrated Marketing Communication selanjutnya yang membuat tertarik diberi nomor tiga, empat, lima hingga enam yang merupakan kegitan terakhir yang membuat responden ingin melanjutkan pendidikan di perguruan tinggi Surabaya ini atau bahkan kegiatan yang tidak diketahui oleh responden bahwa telah dilakukan oleh perguruan tingginya.

Berdasarkan tabel di atas diketahui bahwa kegiatan komunikasi pemasaran yang mempunyai preferensi tertinggi atau yang dianggap paling disukai oleh mahasiswa perguruan tinggi dengan pemberian peringkat 1 adalah diskon beasiswa dengan total 125 responden atau $42 \%$ dari total responden yaitu
300 responden yang mana responden tersebut didapatkan dari kuesioner yang diberikan kepada mahasiswa di salah satu perguruan tinggi swasta di Surabaya. Hal ini sesuai dengan yang disampaikan oleh Lestari (2015) mengenai promosi penjualan yang menyatakan bahwa promosi penjualan merupakan bahan inti dalam kampanye pemasaran yang bersifat jangka pendek dan bertujuan untuk menstimulasi niat pembelian calon konsumen. Dalam hal ini pemberian diskon beasiswa sebagai perwujudan kegiatan promosi penjualan berupa diskon atau penurunan harga yang diberikan secara langsung ke konsumen maupun ke calon konsumen dalam periode tertentu dalam penelitian ini adalah mahasiswa pada perguruan tinggi swasta di Surabaya dan pada hasil dari penelitian ini menunjukan bahwa kegiatan promosi penjualan terbukti sebagai kegiatan IMC yang paling disukai oleh mahasiswa pada perguruan tinggi swasta tersebut yang mana dapat menstimulasi niat pembelian mahasiswa pada perguruan tinggi swasta tersebut. Pada tabel di atas juga dapat diketahui bahwa terdapat beberapa mahasiswa 
pada perguruan tinggi swasta tersebut yang memilih promosi penjualan yang dalam penelitian ini adalah diskon beasiswa sebagai preferensi keduanya dengan jumlah 72 responden atau $24 \%$ dari total responden yaitu 300 responden. Yang mana hal ini juga membutikan bahwa tidak semua mahasiswa pada perguruan tinggi swasta tersebut menyukai pemberian diskon beasiswa sebagai bentuk promosi penjualan. Dari tabel di atas juga dapat diketahui mahasiswa pada perguruan tinggi swasta tersebut yang memilih diskon beasiswa sebagai preferensi kegiatan IMC ketiga dengan jumlah 35 responden atau $12 \%$ dari total responden yang ada yaitu 300 responden. Lalu ada 30 responden atau $10 \%$ dari total responden yaitu 300 responden yang memilih diskon beasiswa pada peringkat keempat sebagai preferensi kegiatan IMC. Lalu juga diketahui 21 responden atau $7 \%$ dari total responden yaitu 300 responden yang memilih diskon beasiswa sebagai preferensi kegiatan IMC pada peringkat kelima dan 17 responden atau $6 \%$ dari total responden yang ada yaitu 300 responden yang memilih diskon beasiswa sebagai preferensi kegiatan komunikasi keenam. Dimana hal ini juga menunjukan bahwa ada beberapa yaitu sebagian kecil mahasiswa yang kurang tertarik atau bahkan tidak mengetahui tetang adanya diskon beasiswa pada perguruan tinggi swasta tersebut. Namun dikarenakan sedikitnya mahasiswa yang memilih diskon beasiswa sebagai preferensi peringkat keenam yaitu hanya $6 \%$ dalam peneltian ini yang menyebabkan diskon beasiswa menjadi kegiatan IMC yang paling disukai oleh mahasiswa pada perguruan tinggi swasta ini.

Pameran pendidikan di sekolah-sekolah menjadi kegiatan IMC yang mempunyai preferensi tertinggi kedua setelah diskon beasiswa yaitu dengan total 78 responden atau setara dengan $26 \%$ kolom peringkat kedua dari total responden yaitu 300 responden yang didapatkan dari mahasiwa pada perguruan tinggi swasta di Surabaya dengan menyebarkan kuesioner. Hal ini sesuai dengan teori menurut Kusniadji (2017) yang menyatakan bahwa personal selling melibatkan komunikasi secara langsung atau face to face dengan calon konsumen, sehingga probabilitas dan kesempatan untuk membujuk konsumen atau calon konsumen menjadi lebih tinggi dari pada alat promosi lainnyat. Penjulan personal atau personal selling juga memiliki tujuan utama sebagai bentuk pengimplementasian dari penjulan personal atau personal selling adalah untuk mengajarkan konsumen, menyediakan penggunaan produk dan bantuan pemasaran dan menyediakan layanan penjualan dan dukungan kepada pembeli (Chitty, Luck, Barker, Valos, \& Shimp, 2012). Dalam hal ini perguruan tinggi swasta tersebut telah berhasil mengimplementasikan kegiatan personal sellingnya dengan cukup baik yaitu dalam penjualan personal perguruan tinggi swasta ini memanfaatkan brosur untuk dibagikan kepada siswa-siswa di sekolah-sekolah SMA yang merupakan tempat penyelenggaraan pameran pendidikan mereka. Pemberian brosur digunakan sebagai dukungan pemasaran untuk memberikan informasi kepada calon konsumen untuk mempermudah dalam penyampaian materi di lain sisi pihak staff marketing pada perguruan tinggi swasta tersebut menjelaskan hal-hal terkait perguruan tinggi swasta tersebut juga memberikan penjelasan tentang penawaran apa saja yang diberikan dengan syarat dan ketentuan yang telah ditetapkan oleh pihak perguruan tinggi swasta tersebut Bentuk kegiatan penjualan personal atau personal selling yang dilakukan oleh perguruan tinggi swasta ini juga terbukti disukai oleh para mahasiswa perguruan tinggi swasta tersebut sehingga menjadi preferensi kegiatan IMC tertinggi kedua. Pada tahap ini tujuan personal selling adalah menarik perhatian. Kegiatan personal selling yang dilakukan dilalui melalui beberapa tahapan yang pertama untuk menarik menurut Kusniadji (2016) adalah Attention (perhatian) calon mahasiswa sasaran menggunakan komunikasi informal seperti berjabat tangan dengan hangat dan selalu tersenyum dalam menghadapi pertanyaan dari calon mahasiswa. Selanjutnya agar Interest (minat) terbentuk, para tenaga penjualan harus selalu menunjukkan dirinya sebagai wakil dari Perguruan tinggi misalnya berseragam atau menggunakan kaos dengan logo perguruan tinggi. Tahap ketiga adalah memnculkan Desire (keinginan) dengan kemampuan untuk mampu menjawab smua pertanyaanyang diajukan oleh calon mahasiswa dan hal ini 
sangat penting untuk meyakinkan mereka. Dari tabel diatas juga dapat diketahui 68 responden atau $23 \%$ dari total responden yang ada yaitu 300 resoponden yang mana menunjukan banyaknya mahasiswa perguruan tinggi swasta tersebut yang memilih pameran pada sekolah SMA sebagai preferensi kegiatan IMC kedua. Lalu 52 responden atau $17 \%$ dari total jumlah responden yang mana menunjukan mahasiswa perguruan tinggi swasta yang memilih pamaren pendidikan pada sekolah SMA sebagai preferensi kegiatan IMC ketiga. Lalu 43 responden atau $14 \%$ dari total responden yang ada memilih pameran pendidikan pada sekolah SMA sebagai preferensi kegiatan IMC keempat. Lalu 35 responden atau $13 \%$ dari total responden yang ada memilih pameran pendidikan ada sekolah SMA sebagai preferensi kegiatan IMC ada peringkat kelima. Sedangkan 24 responden atau 8\% dari total responden yang ada memilih pameran pendidikan pada sekolah SMA sebagai preferensi kegiatan IMC pada peringkat keenam. Dalam hal ini menggambarkan bahwa terdapat sebagian kecil mahasiswa pada perguruan tinggi swasta ini yang tidak tertarik atau tidak mengetahui tentang adanya kegiatan pameran pendidikan pada sekolah SMA.

Kegiatan IMC yang menduduki peringkat ketiga yang cukup disukai oleh mahasiswa perguruan tinggi adalah berita di media massa sebesar $27 \%$ atau 82 orang. Kegiatan yang merupakan implementasi dari kegiatan hubungan masyarakat dan publisitas bertujuan membentuk opini publik yang positif melalui berbagai media. Salah satu media terbaru dan sedang ramai diakses adalah media internet yang semakin memperluas aktivitas serta ruang pemberitaan perguruan tinggi. Bagi 24 anak atau $8 \%$ yang memilih berita di media massa menjadi peringkat pertama adalah mahasiswa yang masih sering membaca pemberitaan di Koran lokal Surabaya karena media massa utama yang dipergunakan untuk publisitas saat penelitian berlangsung. Sebanyak 57 responden atau $19 \%$ pun memilih pemberitaan pada media massa merupakan rangking kedua. Hal ini membuat gambaran menarik tentang anak muda yang masih sering membaca berita di media massa khususnya Koran dan tidak sesuai dengan artikel yang dituliskan oleh Fitri Norhabiba (2015) bahwa pembaca koran akan turun dan berbondong-bondong untuk beralih hanya pada media yang bersifat online. Sebanyak 67 responden atau $22 \%$ memilih kegiatan pemberitaan di media massa ini sebagai urutan ke empat dan sebanyak 51 responden atau $17 \%$ yang memilih sebagai urutan kelima. Yang paling menarik ada lah pemilihan kegiatan pemberitaan di media massa untuk urutan ke-enam hanya 19 responden tau 6\%. Jumlah ini sangat sedikit dan mengingat usaha untuk pemberitaan ini merupakan kegiatan yang non-berbayar pula, bisa menjadi pilihan kegiatan favorit tim marketing untuk memberitakan hal-hal positif. Pemberitaan ini dapat terjadi dengan baik apabila memang sudah ada bagian khusus yang menangani hubungan dengan media massa. Mengingat bahwa media massa saat ini memang tidak hanya Koran, media massa online pun turut berperan. Seperti yang disampaikan oleh Alila, Idola dan Reni (2014) serta Wahid dan Rizki (2018) saat seseorang melihat menggunakan internet memiliki beberapa aktivitas yang mencolok yaitu melakukan berbagai kegiatan dengan menggunakan E-mail, lalu melakukan kegiatan yang bersifat menyenangkan atau aktivitas yang dilakukan sifatnya untuk mencari kesenangan atau hiburan seperti mengunduh video dan gambar dalam pesan singkat, lalu mendengarkan atau mengunduh musik, bermain game serta instant messenger. Kegiatan kegita yang dilakukan dengan menggunakan media internet adalah Information utility atau aktivitas internet yang dilakukan untuk untuk mencari informasi seperti produk, travel, cuaca, dapat pula mencari informasi

mengenai film, musik, buku, berita, pemerintah, pekerjaan, sekolah, kesehatan, keuangan dan informasi tentang politik. Kegiatan yang paling popular adalah aktivitas transaksi atau jual beli melalui media internet seperti membeli sebuah produk, melakukan pemesanan tiket perjalanan, kegiatan perbankan secara online. Kegiatan yang dilakukan lewat media internet juga salah satunya adalah kegiatan membaca. Kegiatan yang dulunya seringkali dianggap membosankan, dapat menjadi kegiatan yang lebih menarik dengan menggunakan media 
yang tepat sesuai dengan perkembangan usia (Hamdani \& Gani, 2019). Pemberitaan media yang menjadi peringkat ketiga dalam penelitian ini menunjukkan bahwa media massa yang digunakan tepat sehingga responden mendapat publisitas yang dilakukan oleh institusi.

Berdasarkan tabel di atas diketahui kegiatan IMC peringkat ke empat yang dipilih oleh para responden yaitu layanan call center dan sosial media dengan total 82 reponden atau sebesar $27 \%$ dari total responden yang mana jumlah total responden adalah 300 responden yang mana merupakan mahasiswa perguruan tinggi swasta ini dan berjenis kelamin laki-laki dan perempuan yang didapatkankan melalui kuesioner. Hal ini sesuai dengan teori menurut Krussell dan Paramita (2016) pemasaran langsung atau direct marketing adalah salah satu fungsi dari IMC yang bahwa pemasaran langsung dibedakan menjadi dua yaitu front end dan back operations di mana front end mencakup penawaran yang diberikan ke konsumen melalui customer database. Sedangkan back end adalah suatu usaha memenuhi harapan konsumen dengan cara membuat produk atau informasi seperti yang diekspektasikan konsumen. Sedangkan Menurut Kotler \& Keller (2009) pemasaran langsung dibagi menjadi beberapa bentuk seperti telepon, online, dan secara pribadi dan terdapat tiga karakteristik yang berbeda dalam sebuah pesan pemasaran langsung, perbedaan yang pertama adalah penyesuaian, dimana pesan dapat dipersiapkan untuk menarik konsumen yang dituju. Yang kedua adalah terkini, yang berarti sebuah pesan dapat dipersiapkan dengan sangat cepat. Yang ketiga adalah interaktif, dimana pesan dapat diubah tergantung pada tanggapan seseorang. Dalam hal ini layanan call center dan sosial media sebagai perwujudan pemasaran langsung sudah dilakukan atau diimplementasikan oleh perguruan swasta ini. Sosial media yang digunakan oleh perguruan tinggi swasta ini sebagai media pemasaran langsung adalah Instagram. Namun berdasarkan tabel di atas dapat diketahui bahwa banyak mahasiswa yang merasa tidak tertarik dan tidak mengetahui tentang adanya layanan call center dan sosial media Instagram yang digunakan oleh perguruan tinggi swasta tersebut. Jika dikaitkan dengan teori yang ada maka terdapat banyak kemungkinan yang dapat terjadi mengenai dampak yang terjadi antara lain implementasi pemasaran langsung yang dilakukan oleh perguruan tinggi swasta ini pada plaform sosial media Instagram kurang interaktif, kurang sesuai dengan target pasar, atau kurang terkini atau kurang update. Namun ada sebagian kecil mahasiswa pada perguruan tinggi tersebut yang memilih pemasaran langsung atau direct marketing yang dalam penelitian ini adalah layanan call center dan menggunkan media sosial Instagram sebagai preferensi utama mereka yang mana dianggap paling menarik dan paling disukai oleh mahasiswa perguruan tinggi swasta tersebut yaitu sebesar 17 responden atau $6 \%$ dari total responden yang ada dimana dalam penelitian ini 300 responden secara total. Lalu diikuti dengan mahasiswa perguruan tinggi swasta ini yang menganggap pemasaran langsung atau direct marketing sebagai bentuk kegiatan IMC berupa layanan call center dan media sosial Instagram sebagai preferensi keduanya yaitu sebesar 31 responden atau 10\% dari jumlah responden yang ada. Lalu diikuti dengan mahasiswa perguruan tinggi swasta ini yang menganggap pemasaran langsung atau direct marketing sebagai bentuk kegiatan IMC berupa layanan call center dan media sosial Instagram sebagai preferensi ketiganya yaitu sebesar 49 responden atau $16 \%$ dari jumlah responden yang ada. diikuti dengan mahasiswa perguruan tinggi swasta ini yang menganggap pemasaran langsung atau direct marketing sebagai bentuk kegiatan IMC berupa layanan call center dan media sosial Instagram sebagai preferensi keempat yaitu sebesar 64 responden atau $21 \%$ dari jumlah responden yang ada. Diikuti dengan mahasiswa perguruan tinggi swasta ini yang menganggap sebagai bentuk kegiatan IMC berupa layanan call center dan media sosial Instagram sebagai preferensi kelima yaitu sebesar 57 responden atau 19\% dari jumlah responden yang ada. diikuti dengan mahasiswa perguruan tinggi swasta ini yang menganggap sebagai bentuk kegiatan IMC berupa layanan call center dan media sosial Instagram sebagai preferensi keenam yaitu sebesar 82 responden atau $27 \%$ dari jumlah responden yang ada. Jika dilihat dari data 
tersebut maka dapat dilihat bahwa dari peringkat satu hingga enam terus mengalami kenaikan jumlah responden dari hal ini dapat disimpulkan bahwa mayoritas mahasiswa pada perguruan tinggi swasta ini tidak tertarik atau tidak mengetahui tentang adanya layanan call center maupun akun media sosial Instagram milik perguruan tinggi swasta ini yang mana hal ini juga dapat menyebabkan pengelolaan dana untuk kegiatan pemasaran menjadi tidak stabil atau terganggu. Melalui data ini juga dapat disimpulkan bahwa layanan call center atau penggunaan media sosial Instagram masih kurang maksimal.

Selanjutnya peringkat ke lima adalah billboard di jalan raya dengan total 36 responden atau $12 \%$ dari total responden. Kegiatan periklanan yang lebih dalam dijelaskan Shimp dan Andrews (2013) serta Poluan, Lumintang, dan Untu (2016) yaitu sebuah kegiatan promosi yang dilakukan dengan mengirimkan pesan di mana pesan tersebut bersifat nonpersonal yang disebarluaskan lewat media berbayar sehingga dapat menjangkau pasar yang lebih luas dan salah satu bentuknya adalah billboard. Dalam hal ini billboard telah di implementasikan oleh perguruan tinggi swasta tersebut sebagai bentuk perwujudan kegiatan periklanan yang merupakan kegiatan pemasaran berbayar. Lalu hal ini juga ditegaskan oleh Chitty (2015) tentang periklanan yaitu suatu bentuk komunikasi pemasaran berbayar yang diberikan dalam bentuk media cetak, media siaran, media digital, media umum lainnya seperti banner, billboard, televisi, atau komunikasi pemasaran langsung yang ditargetkan kepada konsumen. Juga terdapat beberapa indikator dalam advertising menurut Kotler \& Keller (2009) yaitu, Informative advertising merupakan indikator yang memiliki tujuan untuk menciptakan kesadaran merek dan pengetahuan akan suatu produk baru atau fitur baru dari produk yang sudah ada. Kedua, Persuasive advertising merupakan indikator yang bertujuan untuk diskusi, sebagai preferensi, meyakinkan, dan adanya pembelian produk atau layanan. Ketiga, reminder advertising adalah salah satu indikator yang memiliki tujuan untuk mendorong adanya pembelian ulang suatu produk dan jasa. Keempat, reinforcement advertising adalah indikator yang memiliki tujuan untuk meyakinkan konsumen baru bahwa mereka telah melakukan keputusan yang tepat. Berdasarkan tabel di atas, pemasangan billboard pada area jalan raya merupakan salah satu bentuk kegiatan periklanan yang digunakan oleh perguruan tinggi swasta ini yang mana memiliki tujuan yaitu untuk memberi keyakinan kepada calon konsumen atau konsumen sehingga menimbulkan atau mendorong niat pembelian dari konsumen. Kegiatan pemasangan billboard di jalan raya ini juga menjadi salah satu kegiatan IMC yang cukup di sukai oleh mayoritas mahasiswa pada perguruan tinggi swasta tersebut.

Dari tabel di atas dapat diketahui 39 responden atau $13 \%$ dari total responden yang ada yaitu 300 responden memilih billboard sebagai preferensi kegiatan IMC pada peringkat kedua yang disukai para mahasiswa pada perguruan tinggi swasta tersebut. Lalu 39 responden atau $13 \%$ dari total responden yang ada yang memilih billboard sebagai preferensi kegiatan IMC pada peringkat ketiga yang disukai oleh mahasiswa pada perguruan tinggi swasta tersebut. Lalu 51 resonden atau 17\% dari total responden yang ada yang memilih billboard sebagai preferensi kegiatan IMC pada peringkat keempat yang disukai oleh mahasiswa pada perguruan tinggi swasta tersebut. Lalu 69 responden atau 23\% dari total resonden yang ada yang memilih billboard sebagai preferensi kegiatan IMC pada peringkat kelima yang disukai oleh mahasiswa pada perguruan tinggi swasta tersebut. Lalu 66 responden atau $22 \%$ dari total responden yang ada yang memilih billboard sebagai preferensi kegiatan IMC pada peringkat keenam yang disukai oleh mahasiswa pada perguruan tinggi swasta tersebut. Dalam hal ini terlihat bahwa ada beberapa mahasiswa yang memilih peringkat keenam yang mana jumlahnya cukup banyak namun yang memilih kegiatan billboard ini pada peringkat pertama juga cukup banyak. Hal ini menggambarkan ada beberapa mahasiwa yang menyukai dan ada beberapa mahasiswa yang tidak menyukai kegiatan billboard ini dikarenakan kurang menarik.

Pada tabel di atas juga dapat diketahui beberapa kegiatan komunikasi pemasaran yang menjadi urutan terakhir atau ke enam 
atau tidak diketahui oleh mahasiswa perguruan tinggi swasta tersebut mulai dari yang paling dianggap tidak menarik atau tidak diketahui yaitu parents dinner dengan total 92 mahasiswa atau $31 \%$ dari total responden yaitu 300 responden di mana data responden tersebut didapat dari kuesioner yang di sebarkan kepada mahasiswa pada perguruan tinggi tersebut. Dimana hal ini menunjukan mahasiswa merasa tidak tertarik dan tidak mengetahui tentang adanya kegiatan parents dinner yang diadakan oleh perguruan tinggi swasta bersangkutan. Hal ini sesuai dengan teori menurut Anjelin dan Wahyudi (2018) yang menyatakan bahwa acara dan pengalaman merupakan serangkaian kegiatan yang diselenggarakan/disponsori oleh perusahaan dimana dalam kegiatan tersebut terdapat hubungan dengan suatu brand. Yang mana hal tersebut juga dapat memungkinan komunikasi antara perusahaan atau merek bersangkutan dengan audience yang potensial. Dalam hal ini parents dinner sebagai perwujudan dari kegiatan acara dan pengalaman namun kegiatan parents dinner tersebut tidak cukup membuat para mahasiswa tertarik. Pada tabel diatas juga dapat diketahui responden yang memilih kegiatan parents dinner sebagai bentuk kegiatan IMC pada peringkat pertama atau yang paling disukai yaitu sebanyak 20 responden atau $7 \%$ dari total responden yang ada yaitu 300 responden. Lalu juga diketahui 33 responden atau $11 \%$ dari responden yang ada yang memilih parents dinner sebagai preferensi kegiatan IMC peringkat kedua. Lalu 43 responden atau $14 \%$ dari total responden yang ada ada yang memilih parents dinner sebagai preferensi kegiatan IMC peringkat ketiga. Lalu 45 responden atau $15 \%$ dari total responden yang ada yang memilih parents dinner sebagai preferensi kegiatan IMC peringkat keempat. Lalu 67 responden atau $22 \%$ dari total responden yang ada yang memilih parents dinner sebagai preferensi kegiatan IMC peringkat kelima. Lalu 92 responden atau $31 \%$ dari total responden yang ada yang memilih parents dinner sebagai preferensi kegiatan IMC peringkat keenam. Dalam hal ini dapat dilihat bahwa banyaknya responden selaku mahasiswa perguruan tinggi swasta tersebut yang memilih peringkat keenam dengan kondisi di mana dari peringkat satu sampai enam mengalami kenaikan jumlah responden atau dianggap tidak menarik sehingga dapat disimpulkan bahwa parents dinner bukan merupakan kegiatan komunikasi pemasaran yang efektif untuk dilakukan sebagai bentuk pengimplementasian kegiatan acara dan pengalaman dikarenakan biaya yang dikeluarkan untuk mengadakan parents dinner cukup besar namun dampak yang didapat oleh perusahaan maupun konsumen adalah sangat minimum.

Berbagai kegiatan yang sudah dilakukan sebagai sarana untuk menyebarluaskan berita positif ini dilakukan untuk menarik minat calon mahasiswa. Dengan adanya hasil urutan atau peringkat diatas, dapat dilihat kegiatan pemasaran yang paling menarik diberikan urutan atau peringkat pertama. Berbagai kegiatan yang dilakukan sudah termasuk dalam rangkaian kegiatan integrated marketing communication.

\section{SIMPULAN}

Berdasarkan hasil analisis data di atas, peneliti dapat menarik kesimpulan yaitu:

a) Perguruan tinggi swasta ini sudah melakukan enam kegiatan integrated marketing communication dengan baik yang dijalankan selama masa promosi dilakukan untuk menarik minat para calon mahasiswa.

b) Urutan hasil rangking atau peringkat yang didapatkan dari hasil penelitian yang dilakukan adalah:

1) Diskon Beasiswa

2) Pameran pendidikan di sekolah

3) Berita di media massa

4) Adanya layanan call center dan medsos

5) Billboard di jalan raya

6) Parents Dinner

c) Urutan yang didapatkan dari hasil penelitian dapat menjadi masukkan dalam pemilihan kegiatan pemasaran perguruan tinggi untuk kedepannya dengan berbagai pertimbangan.

d) Kegiatan IMC yang dianggap tidak menarik atau tidak diketahui oleh mahasiswa pada perguruan tinggi tersebut tetap tidak menutup kemungkinan untuk 
dapat mengalami perkembangan jika perguruan tinggi tersebut dapat memilih media dan bentuk kegiatan yang lebih tepat.

\section{DAFTAR PUSTAKA}

Adisetiawan, R. (2016). Faktor yang mempengaruhi lulusan SMA dalam Memilih Fakultas Ekonomi Program Studi Manajemen Universitas Batanghari. Jurnal Ilmiah Universitas Batanghari Jambi, 2.

Akkas, N. (2016). Pengaruh Komunikasi Pemasaran Terpadu Terhadap Citra Perusahaan dan Dampaknya Terhadap Kepuasan Pelanggan Membeli Mobil Pada P.T. Hadhi Kalla Cabang Palu. e-Jurnal Katalogis, 24-36.

Amirullah, S. M. (2015). Metode Penelitian Manajemen. Malang: Bayumedia Publishing Malang.

Anjelin, C., \& Wahyuni, I. I. (2018). Strategi Komunikasi Pemasaran Terpadu Bandung Makuta Cake Dengan Menggunakan IMC Model Dwi Sapta . Jurnal Communication, 80.

Bungin, B. (2015). Metodologi Penelitian Sosial dan Ekonomi . Jakarta: Prenademedia Group.

Chitty, B. L. (2015). Integrated Marketing Communications (4th ed.). Melbourne, Australia: Cengage Learning Australia.

Chitty, B., Luck, E., Barker, N., Valos, M., \& Shimp, T. A. (2012). Integrated Marketing Communications. South Melbourne: National Library of Australia Cataloguing.

Databoks. (2017, Mei 5). berapa jumlah perguruan tinggi di indonesia. Retrieved November 7, 2019, from katadata.co.id:

https://databoks.katadata.co.id/datap ublish/2017/05/05/berapa-jumlahperguruan-tinggi-di-indonesia

Direktorat, K. (2016, September 20). Statistik. Retrieved November 7, 2019, from Kelembagaan
Direktorat https://kelembagaan.ristekdikti.go.id/ index.php/statistik-5/

Gurmilang, A. (2015). Komunikasi Pemasaran Sebagai Metode Promosi Untuk Usaha Kecil Menengah. Jurnal Universitas Pembangunan Jaya, 126140.

Hamdani, S., \& Gani, E. (2019). Nilai-Nilai Pendidikan Karakter Dalam Cerpen Koran Harian Singgalang Periode Januari-April 2019. Jurnal Pendidikan Bahasa dan Sastra Indonesia, 423-429.

Hermawan, A. (2012). Komunikasi Pemasaran. Jakarta: Penerbit Erlangga.

Isharyadi, Kurniawan, F., Irwansyah, \& Ruliana, P. (2019). Integrated Marketing Communication Sekolah Tinggi Desain Interstudi sebagai strategi keluar dari krisis. Journal o Communication Studies, 30.

Ismail, R., \& Helmawati. (2018). Meningkatan SDM Berkualitas Melalui Pendidikan. Bandung: Alfabeta,CV.

Keke, Y. (2015). Komunikasi Pemasaran Terpadu Terhadap Brand Awareness. Jurnal Manajemen Bisnis Transportasi Dan Logistik, 172-186.

Kotabe, M. \&. (2014). International Marketing (4th ed.). Milton, Australia.: John Wiley \& Sons Australia, Ltd.

Kotler, P. K. (2009). Manajemen Pemasaran, Edisi 13, Jilid 2. Ciracas, Jakarta: Penerbit Erlangga.

Kriyantono, R. (2006). Teknik Praktis Riset Komunikasi. Jakarta: PT Kencana Perdana.

Krussell, J. G., \& Paramita, E. L. (2016). Komunikasi Pemasaran Terpadu dan Ekuitas Merek Alfamart. Jurnal Management dan bisnis , 30.

Kusniadji, S. (2016). Strategi Komunikasi Pemasaran Dalam Kegiatan Pemasaran Produk Consumer Goods. Jurnal Komunikasi, 83-98.

Kusniadji, S. (2017). Kontribusi Penggunaan Personal Selling Dalam Kegiatan Komunikasi Pemasaran Pada Era Pemasaran Masa Kini . Jurnal Komunikasi, 176-183. 
Lestari, R. (2015). Sales Promotion SebagaiI Strategi Komunikasi Pemasaran Mobil Low Cost Green Car Daihatsu Ayla pada PT. Astra Internasional TBK Cabang Ciledug Kota Tangerang. Jurnal Ilmu Komunikasi, 89-90.

Lestari, S. P. (2016). Hubungan Komunikasi Pemasaran dan Promosi Dengan Keputusan Memilih Jasa Layanan Kesehatan. Majalah Ilmiah Inspiratif, 1-19.

Norhabiba, F. (2015). Akses Media Baru Oleh Remaja SMA Kota Semarang dan Hubungannya Dengan. Jurnal Interaksi, 132-138.

Poluan, J. G., Lumintang, G. G., \& Untu, N. V. (2016). Pengaruh Periklanan Terhadap Keputusan Pembelian Minuman Coca Cola . Jurnal EMBA, 671-681.

Prabela, C. V., Kumadji, S., \& Mawardi, M. K. (2016). Pengaruh Integrated Marketing Communication (IMC) dan Public Relations Terhada Citra merek dan Keputusan Pembelian. Jurnal Administrasi Bisnis , 158.

Pramiyanti, A., Putri, I. P., \& Nureni, R. (2014). Motif Remaja Dalam Menggunakan Media Baru. KomuniTi, 95-103.

Putri, P. K. (2016). Aplikasi PendekatanPendekatan Persuasif Pada Riset Komunikasi Pemasaran: Iklan Melibatkan Penciptaan dan Penerimaan Pesan Komunikasi Persuasif Mengubah Perilaku Pembelian. The Messenger, 1-16.

Raya, M. K. (2016). Marketing Jasa di Institusi pendidikan . Falasifa, 23-24.

Shimp, T. A., \& Andrews, J. C. (2013). Advertising, Promotion, and other aspects of Integrated Marketing Communication. Mason: Cengage Learning .

Siyoto, D., \& Sari, N. (2016). Aplikasi dan Teknik Survey Bidang Kesehatan. Yogyakarta: Literasi Media .

Srisusilawati, P. (2017). Kajian Komunikasi Pemasaran Terpadu Dalam Mendorong Keputusan Pembelian Jasa Perbankan. Jurnal Ekonomi dan Keuangan Syariah, 1-19.
Supriadi, B., \& Roedjinandari, N. (2017). Perencanaan dan Pengembangan Destinasi Pariwisata. Malang: Universitas Negeri Malang.

Surjaweni. (2015). Metodologi Penelitian Bisnis dan Ekonomi . Yogyakarta: PT. Pustaka Baru.

Teguh, M., \& Ciawati, S. T. (2020). Perancangan Strategi Digital Marketing Communication Bagi Industri Perhotelan Dalam Menjawab Tantangan Era Posmoderen. Bricolage, 51-63.

Ulfa, R., \& Marta, R. F. (2016). Implementasi Komunikasi Pemasaran Terpadu Pada Yayasan Nurul Ibad Jakarta Timur. Bricolage, 71-81.

Utami, M. A., Lestari, M. T., \& Putri, B. P. (2016). Analisis Strategi Komunikasi Pemasaran SMB Telkom University Tahun 2015/2016 melalui media sosial instagram. eProceding of Management, 861.

Wahid, U., \& Rizki, M. F. (2018). Upaya Komunikasi Pemasaran Terpadu Televisi Lokal Melalui Budaya Lokal. Jurnal Kajian Komunikasi, 160-174.

Wardhani, W., Sumarwan, U., \& Yuliati, L. N. (2015). Pengaruh Persepsi dan Preferensi Konsumen Terhadap Keputusan Pembelian Hunian Green product. Jurnal Manajemen dan Organisasi , 47.

Wibowo, E. A. (2014). Analisa STrateg Penempatan Merek Sebagai Bagian Dalam Komunikasi Pemasaran Terpadu. Jurnal Dimensi, 1-24.

Wono, H. Y. (2018). Preferensi Mahasiswa Terhadap Marketing Communication Mix. Jurnal Komunikasi Prefesional , 62-75. 
